Я. В. Рогальська, І. В. Кубей, Т. О. Воронцова, Л. А. Волянська, У. М. Мудрик, Н. М. Ярема, К. Т. Глушко

ДВНЗ “Тернопільський державний медичний університет імені I. Я. Горбачевського МОЗ України”

\title{
ШЛЯХИ ОПТИМІЗАЦІЇ ПРАКТИЧНОЇ ПІДГОТОВКИ МАЙБУТНІХ ЛІКАРІВ ПІД ЧАС ПРОХОДЖЕННЯ ЛІТНЬОЇ ВИРОБНИЧОЇ ПРАКТИКИ
}

\author{
Ya. V. Rogalska, I. V. Kubei, T. O. Vorontsova, L. A. Volyanska, U. M. Mudrik, \\ N. M. Yarema, K. T. Glushko \\ I. Horbachevsky Ternopil State Medical University \\ WAYS TO OPTIMIZE THE PRACTICAL TRAINING OF FUTURE \\ DOCTORS DURING THE SUMMER PRODUCTION PRACTICE
}

\begin{abstract}
Мета роботи - підвищити ефективність та якість навчання студентів шляхом оптимізації практичної підготовки майбутніх лікарів під час проходження літньої виробничої практики.

Основна частина. Перед вищою медичною освітою стоїть завдання - забезпечити високу професійну підготовку фахівців. Виробнича практика студентів є однією з форм навчального процесу і його суттєвою складовою частиною. Велику роль у становленні особистості майбутнього лікаря відіграє формування ціннісного ставлення до людського життя. Працюючи зі студентами, доцільно акцентувати увагу на тому, що специфіка їх майбутньої професійної діяльності потребує пріоритетного прояву таких моральних якостей, як гуманність, емпатійність, толерантність, чесність, а надто в роботі з такими категоріями, як діти, люди з особливими потребами, безнадійно хворі тощо. В процесі професійної освіти студентів-медиків підготовка різноманітних заходів волонтерських загонів сприяє формуванню людяності, співчуття, навиків психологічної підтримки та спілкування з особливою категорією пацієнтів. Як приклад, наш досвід роботи студентів-медиків у Тернопільському обласному спеціалізованому будинку дитини та соціальному центрі ТБФ “Карітас” під час проходження літньої виробничої практики.

Висновок. Формування моральних якостей студентів вищих медичних навчальних закладів - основа особистісного становлення і потребує розробки конкретної моделі та залучення до навчально-виховної роботи різноманітних методик та підходів, рекомендуємо долучати студентів у період літньої виробничої практики до різноманітних заходів волонтерських загонів (відвідування дитячих будинків, онкологічних лікарень для дітей, соціальних організацій тощо) в рамках конструктивного співробітництва.
\end{abstract}

Ключові слова: виробнича практика; шляхи оптимізації.

The aim of the work - to increase the effectiveness and quality of student training by optimizing the practical training of future doctors during the summer production practice.

The main body. The task of the higher medical education is to provide high professional training of specialists. The practice of students in clinics is one of the forms in the educational process and its essential component. A significant role in the formation of the future physicians' personality is played by the formation of a value attitude to human life. Working with students, it is necessary to emphasize that the specificity of their future professional activity requires priority manifestation of such moral qualities as humanity, empathy, tolerance, honesty, especially in working with such categories as children, with special needs, hopelessly ill, etc. In the process of professional education of medical students, the preparation of various activities of volunteer units contributes to the formation of humanity, compassion, new skills of psychological support and communication with a special category of patients. As an example, our experience of medical students working in the Ternopil Regional Specialized Child's Home and in the international prosperity fund Caritas in Ternopil during their summer practice.

Conclusion. Formation of moral qualities of students of higher educational institutions is the basis of personal formation and requires the development of a specific model and the attraction to teaching and educational work of various methods and approaches. We suggest involving students during the summer practice in volunteer work (visiting orphanages, oncology departments for children, social organizations, etc.) in the framework of constructive cooperation.

Key words: industrial practice; ways to optimize.

(c) Я. В. Рогальська, І. В. Кубей, Т. О. Воронцова та ін. 
Вступ. Реформування медичної галузі - важливий етап виконання Угоди про асоціацію між Україною та ЄС, відповідно до Європейського плану дій. Міністерством охорони здоров'я у серпні 2014 р. запропоновано Національну стратегію реформування системи охорони здоров'я в Україні на період 20152020 рр., що є складовою Національного плану дій з реформування, котрий був проголошений Указом Президента України від 12 січня 2015 р. № 5/2015 "Про Стратегію сталого розвитку “Україна - 2020" та урядом України (програма діяльності Кабінету Міністрів України, схвалена Постановою Верховної Ради України від 11 грудня 2014 р. № 26-VIII) [1]. Реформування медичної освіти України - це не лише можливість для майбутнього лікаря стати конкурентоспроможним фахівцем та обирати місце праці у будь-якій країні Європи, а й підвищення якості медичної допомоги для кожного в нашій країні. Планка вимог і відповідальності дуже висока, науково-технічний прогрес спонукає медицину до безперервного розвитку, а лікарів - до набуття нових знань, навичок, майстерності. Пріоритетним напрямком щодо розвитку є перш за все підвищення якості освіти, особливо базової - додипломної ланки [2]. Адже підготовка лікарів завжди вимагає не лише засвоєння теоретичних знань, досконалого володіння практичними навиками, а й поєднання їх із високими людськими, морально-етичними якостями усіх, хто обрав свою професію у цій сфері [3]. Тому досягнення цього можливо шляхом удосконалення технологій та форм навчання, особливо клінічних дисциплін, включаючи невід’ємну частину навчання - літню виробничу практику студентів старших курсів.

Мета роботи - підвищити ефективність та якість навчання студентів шляхом оптимізації практичної підготовки майбутніх лікарів під час проходження літньої виробничої практики.

Основна частина. Сьогодні перед вищою медичною освітою стоїть завдання - забезпечити високу професійну підготовку фахівців, тому що якість медичної допомоги в найближчому майбутньому безпосередньо залежить від рівня підготовки молодих спеціалістів, випускників медичних вузів [4]. В теперішній час організація навчального процесу здійснюється за кредитно-модульною системою, метою впровадження якої у вищих медичних навчальних закладах України є підвищення якості вищої освіти фахівців і забезпечення на цій основі конкурентоспроможності випускників та престижу української вищої освіти у світовому освітньому просторі. Проведення виробничої практики на 4 i 5 курсах вищих медичних навчальних закладів України є важливим етапом у формуванні та становленні майбутнього лікаря. Така практика проводиться в літній період протягом 4 тижнів (6 кредитів, 180 годин) у лікувально-практичних закладах охорони здоров'я [5].

На особливу увагу заслуговує той факт, що даний вид практики $є$ першим самостійним кроком студента-медика після успішного завершення 4 курсу в стаціонарі, а після 5 курсу - в поліклініці, оскільки догляд за хворими та сестринська практика на IIIII курсах раніше частково також проходили влітку, то на даний час ці два предмети викладаються як практичні заняття упродовж семестру. Виробнича практика студентів $є$ однією з форм навчального процесу і є його суттєвою складовою частиною. Велику роль у становленні особистості майбутнього лікаря відіграє формування у студентів ціннісного ставлення до людського життя. Навчання і виховання нерозривно пов'язані, вони формують образ лікаря-професіонала, людини-громадянина.

Навчання у вищій медичній школі на сьогодні асоціюється із все більшою часткою використання комп'ютерної техніки та сучасних інформаційних технологій, симуляційних методів навчання, що безумовно необхідне для засвоєння та відпрацювання алгоритмів невідкладних станів та здобуття високого професійного рівня, проте моральні та людські якості, гуманність та співчуття, відповідальність, розвиток клінічного мислення неможливі без контакту між студентом і хворим. Тому важлива інтеграція цих сфер у навчанні майбутніх лікарів.

Процес формування моральних якостей студентів має свою специфіку для студентів початкового періоду навчання та студентів старших курсів. Працюючи зі студентами старших курсів, доцільно акцентувати увагу на тому, що специфіка їх майбутньої професійної діяльності потребує пріоритетного прояву таких моральних якостей, як гуманність, емпатійність, толерантність, чесність, особливо в роботі з такими категоріями, як діти, люди з особливими потребами, безнадійно хворі тощо. Саме тому основним напрямом процесу формування моральних якостей майбутніх лікарів стає їх практична робота, зокрема під час проходження літньої виробничої практики. Необхідно відзначити, що в процесі професійної освіти студентів-медиків під- 
готовка різноманітних заходів волонтерських загонів (відвідування воєнного госпіталю, дитячих будинків, онкологічних лікарень для дітей тощо) сприяє формуванню людяності, співчуття, навиків психологічної підтримки та спілкування з особливою категорією пацієнтів.

Як приклад, наш досвід роботи студентів-медиків у Тернопільському обласному спеціалізованому будинку дитини та соціальному центрі ТБФ “Карітас” під час проходження літньої виробничої практики.

Згідно з підписаною угодою між ТДМУ та соціальним центром ТБФ “Карітас”, а також співпрацею вузу з Тернопільським обласним спеціалізованим будинком дитини, когорта практикантівп’ятикурсників виявила бажання працювати в названих закладах. Залучались студенти добровільно в період проходження літньої виробничої практики з циклу “Педіатрія” після того, як вони завершували роботу на основній поліклінічній базі. Попередньо викладач оцінював рівень теоретичної підготовки студентів, далі надавав всі необхідні консультації щодо особливостей медичної допомоги у подібних закладах, надалі вони працювали під патронажем керівників практики та персоналу закладу. Під час інструктажу зверталась увага на те, що професія лікаря передбачає роботу з різними категоріями населення, тому потрібно бути готовими до цього.

В результаті такої співпраці студенти не лише краще засвоїли основні навички, які включені до програми проходження практики, а й розвинули в собі професійно значущі якості, які виступають умовою успішного опанування професією: відчуття відповідальності, співчуття, прагнення допомогти, отримали задоволення від перших самостійних

\section{Список літератури}

1. Про Стратегію сталого розвитку “Україна - 2020” : Указ Президента України від 12 січня 2015 р. № 5/2015 [Електронний ресурс]. - Режим доступу : http://zakon2. rada.gov.ua/laws/show/5/2015.

2. Підходи до підготовки сімейних лікарів в Україні та країнах Європи / Ю. В. Вороненко, О. Г. Шекера, В. І. Ткаченко [та ін.] // Український медичний часопис. 2014. - № 3. - С. 101-103.

3. Скробач Н. В. Самостійна робота студентів вищих навчальних закладів як важливий елемент сучасної підготовки фахівців / Н. В. Скробач, І. Т. Гаврик, успішних кроків; заслужили виключно схвальні відгуки від працівників закладів.

Потрібно зазначити, що студенти Тернопільського державного медичного університету імені I. Я. Горбачевського, надихнувшись отриманим досвідом під час проходження виробничої практики, стали волонтерами і регулярно відвідують Тернопільський обласний спеціалізований будинок дитини $з$ міні-лекціями на різні теми для дітей старшого віку та з розвиваючими іграми для молодших, а також готують виступи і презентації санітарно-просвітницького змісту в рамках співпраці із соціальним центром ТБФ “Карітас”.

Висновки. Отже, процес формування моральних якостей студентів вищих медичних навчальних закладів - основа особистісного становлення як майбутнього лікаря і потребує розробки конкретної моделі формування моральних якостей та залучення до навчально-виховної роботи зі студентами різноманітних методик та підходів, виховання та морального впливу.

Цінним у процесі професійної освіти студентівмедиків вважаємо залучення їх до різноманітних заходів волонтерських загонів (відвідування дитячих будинків, онкологічних лікарень для дітей, соціальних організацій тощо), що сприяє формуванню людяності, співчуття, якостей фахівця, які служать успішному виконанню професійної діяльності, особистісному зростанню та вдосконаленню; тому рекомендуємо заохочувати студентів у період літньої виробничої практики долучатись до подібних заходів у рамках конструктивного співробітництва. Такі методи збагачують арсенал викладання у вищій медичній освіті.

Ю. В. Дельва // Галицький лікарський вісник. - 2014. № 2. - С. 110-111.

4. Успіхи і проблеми викладання сімейної медицини на додипломному етапі: досвід Тернопільського державного медичного університету / Л. С. Бабінець, І. О. Боровик, Н. Є. Боцюк [та ін.] // Сімейна медицина. - 2013. № 4. - С. 28-31.

5. Про вищу освіту : Закон від 01.07.2014 р. № 1556-VII [Електронний ресурс]. - Режим доступу : http://zakon3. rada.gov.ua/laws/show/1556-18. 


\section{References}

1. Pro Stratehiiu staloho rozvytku "Ukraina - 2020" [About the Strategy of Sustainable Development "Ukraine 2020”]. Ukaz Prezydenta Ukrainy vid 12 sichnia 2015 r. № 5/2015 - Decree of the President of Ukraine dated January 12, 2015 № 5/2015. Retrieved from: http://zakon2.rada. gov.ua/laws/show/5/2015.

2. Voronenko, Yu.V., Shekera, O.H., Tkachenko, V.I., Medvedovska, N.V., \& Krasnov, V.V. (2014). Pidkhody do pidhotovky simeinykh likariv v Ukraini ta krainakh Yevropy [Approaches to the family doctors' training in Ukraine and European countries]. Ukrainskyi medychnyi chasopys Ukrainian Medical Journal, 3, 101-103 [in Ukrainian].

3. Skrobach, N.V., Havryk, I.T., \& Delva, Yu.V. (2014). Samostiina robota studentiv vyshchykh navchalnykh zakladiv yak vazhlyvyi element suchasnoi pidhotovky fakhivtsiv [Independent work of students of higher educational institutions as an important element of modern training of specialists]. Halytskyi likarskyi visnyk - Galician Medical Journal, (2), 110-111 [in Ukrainian].

4. Babinets, L.S., Borovyk, I.O., Botsiuk, N.Ye., Vorontsov, O.O., Mihenko, B.O., Riabokon, S.S., ... Yasnii, O.R. (2013). Uspikhy i problemy vykladannia simeinoi medytsyny na dodyplomnomu etapi: dosvid Ternopilskoho derzhavnoho medychnoho universytetu [Achievements and problems of teaching family medicine on undergraduate level: experience of Ternopil State Medical University]. Simeina medytsyna - Family Medicine, 4, 2831 [in Ukrainian].

5. Zakon “Pro vyshchu osvitu” vid 01.07.2014 № 1556VII [About Higher Education: Law dated 01.07.2014 No. 1556-VII]. Retrieved from: http://zakon3.rada.gov.ua/laws/ show/1556-18. 